\title{
Scientific Exchanges between France and Brazil in the History of Psychology. The Role of Georges Dumas between 1908 and 1946*
}

Intercambio científico entre Francia y Brasil en la historia de la psicología - el papel de Georges Dumas entre 1908 y 1946

Recibido: diciembre 13 de 2013 | Revisado: febrero 16 de 2014 | Aceptado: julio 17 de 2014

\author{
Carolina S. Bandeira de Melo ** \\ Regina Helena de Freitas CAmpos ****
}

doi.org/10.11144/Javeriana.upsy13-5.sefb

Para citar este artículo: Bandeira de Melo, C. S., \& De Freitas Campos, R. H. (2014). Scientific Exchanges between France and Brazil in the History of Psychology. The Role of Georges Dumas between 1908 and 1946. Universitas Psychologica, 13(5), 1681-1695. http://dx.doi.org/10.11144/Javeriana. upsy13-5.sefb

We sincerely thank Donald Cross, as the early reader of this paper.

** PhD Student at École de Hautes Études en Sciences Sociales, Paris, France and Faculdade de Educação, Universidade Federal de Minas Gerais. Scholarship from CAPES. E-mail : carolina.bmelo@yahoo. com.br

**** Professor at Faculdade de Educaçao, Universidade Federal de Minas Gerais. E-mail: regihfc@terra. com.br
A B S T R A C T

This article presents the role of Georges Dumas in the development of Brazilian psychology in the first half of the twentieth century. France had at that moment a major influence on Brazilian cultural and scientific development, including the field of psychology. Georges Dumas had a prominent presence in Brazil, acting as a gatekeeper when choosing French scholars to give conferences and classes in Brazil between 1908 and 1940 as a representative of the French cultural tradition. The bibliography of Georges Dumas's Traité de Psychologie, published in 1922-1923, shows a selection of Brazilian scholars who interacted with the author 1900's ans 1940's. The political context of French-Brazilian exchanges and the names of professors involved in the French mission in Brazil in the field of psychology were studied. The French cultural influence in Brazil is interpreted as a strategy aimed at contributing to the solution of Brazilian problems, and it helped to change the image of Brazil in Europe. In addition, scientific exchanges promoted the extension of the French diplomatic network.

Keywords

History of psychology, scientific exchanges between France and Brazil, Georges Dumas 


\section{Introduction}

The role of Georges Dumas in the development of Brazilian psychology is studied with the purpose of understanding Franco-Brazilian academic and scientific exchanges in the area during the first half of the twentieth century. Georges Dumas's contributions are examined by considering Brazilian and French studies and sources. From the beginning of the century, Georges Dumas played a crucial role in shaping intellectual relations between France and Latin America, as chair of Experimental Psychology at the Sorbonne University beginning in 1902. This article intends to be an introduction to the study of the presence of France in Brazilian psychology and also to inspire further studies.

France had a major influence on the cultural and scientific development of Brazil. During the first half of the twentieth century many Brazilians went to France to study, they were fluent in French. The interaction with French scholars was also pivotal in the constitution of Brazilian psychology. Cabral (2004) noted that, in the beginning of the twentieth century, Brazilian psychology was inspired almost exclusively by French psychology. Even if a diversification of influences occurred afterwards, very often Europeans and Americans were known in Brazil only through citations by French authors or in French books. Rocha (2004) points out that since the nineteenth century the presence of Brazilian students elite in France for intellectual and professional improvements was usual. At the time, French scientific theories and philosophical doctrines were prevalent among Brazilian scholars.

Suppo (1999) studied French cultural policies in Brazil between 1920 and 1950, and he refers to Georges Dumas as a central figure in shaping the relationship between the two countries. Dumas's role went beyond the sphere of psychology. French politicians frequently consulted Dumas about the exchanges with Brazil and other countries in Latin America. He established multiple partnerships between France and Latin America, being involved in a mission that was responsible for the establishment of French institutions in Brazil and for promoting French culture. He promoted the establishment of
French educational institutions, such as the Lycées (Secondary Schools) and the Institut franco-brésilien de haute culture (French-Brazilian institute for higher culture) in Rio de Janeiro and in São Paulo (in 1922 and 1925, respectively). In the following decade, Georges Dumas recommended French teachers for the newly created University of São Paulo (USP) and later for the University of Brazil in Rio de Janeiro and the University of Porto Alegre.

In spite of the central role he played in the French-Brazilian intellectual and cultural network, George Dumas is not sufficiently studied in the history of psychology, be it French or Brazilian. The Laboratory of Experimental Psychology of the Psychiatric Clinic at the Hospital Nacional dos Alienados (National Hospital for the Alienated), in Rio de Janeiro, was one of the first laboratories of psychology to be established in the country. According to Antunes (2005), the creation of this laboratory was due to the interaction of Georges $\mathrm{Du}$ mas and Maurício de Medeiros ${ }^{1}$ in the laboratory of Psychology at the Hôpital Sainte Anne (Sainte Anne Hospital) while Medeiros was a student in France. A couple of years later, in 1908, Dumas was invited by Medeiros to give some lectures in Brazil. Upon his departure, the Groupement des Universités et Grandes écoles de France pour les relations avec l'Amérique latine (Group of Universities and Colleges of France for relations with Latin America), recently created, asked Georges Dumas to seek opportunities for scientific and cultural cooperation with Brazil.

From that time on, actions from the Groupement in Brazil increased significantly. At first, major conferences were held in Brazil and other Latin American countries, led by famous French scientists. Later, during the 1930s, French profes-

1 Maurício de Medeiros (1885 - 1966) was a pharmacist and medical doctor. He wrote papers on psychology and attended Georges Dumas's courses at the Sorbonne (Campos, 2001). According to Lourenço Filho (1955), because of his work with Georges Dumas in France, Maurice de Medeiros was awarded the title of foreign member of the Société Française de Psychologie. After that stay in Paris, Medeiros settled in for several years at the Laboratory of Experimental Psychology at the Hospital Nacional de Alienados, in Rio de Janeiro. Besides practicing, this laboratory produced knowledge that helped the development of Brazilian psychology. 
sors went to Brazil to teach at the newly established universities. Georges Dumas was responsible for hiring, from his network, professors to give lectures and to participate in French missions at Brazilian universities. In addition, Georges Dumas organized the Traité de Psychologie (1923-1924), the second (revised and expanded) edition of which - entitled Nouveau Traité de Psychologie (The New Treatise of Psychology), edited from 1930 onwards, in 10 volumes - contains ten studies written by Brazilian authors.

\section{Georges Dumas's Network}

Georges Dumas was born on March 6, 1866, in Lédignan, France. A student at the Ecole Normale Supérieure (Higher Normal School) and professor (agregé) of philosophy, he decided to study medicine, apparently convinced by Théodule Ribot, who recommended medicine and philosophy for the study of psychology. In 1897, Dumas was appointed head of the Laboratory of Psychology at the clinic for mental illness of the Faculty of Medicine of Paris, and in 1900 he defended his thesis at the Faculty of Letters. In 1902, Georges Dumas succeeded Pierre Janet at the Sorbonne. In 1912, he was awarded the chair of Experimental Psychology at the Faculty of Letters of Paris. In the following years he became a member of the Académie de Médecine de France (France Medical Academy) and of the Académie des Sciences Morales et Politiques (Moral and Political Sciences Academy); and was appointed as president of many scientific societies, such as the Société médico-psychologique (MedicalPsychological Society) (Wallon, 1968).

Together with Pierre Janet (1859-1947), Georges Dumas founded the Société Française de Psychologie (French Society of Psychology). According to Carroy, Ohayon, and Plas (2006), he did not really attain a significant reputation, and historians of French psychology briefly mention him. However, his role was essential to the scientific circulation between France and Latin America during the first half of the twentieth century. In Brazil, he was regarded as a friend by scholarly and political elites, often mentioned in the Brazilian press of the time, and highly quoted in the academic community. $\mathrm{He}$ received the title of citizen of Rio de Janeiro and of Doctor honoris causa (honorary doctorate) from Latin American universities as the Universidade do Distrito Federal (University of the Federal District), in Rio de Janeiro, in 1937 (A Noite 2 , 1937, August 3). He maintained a constant exchange with Brazilian politicians and scientists. According to Ferreira (1999), Georges Dumas was deeply familiar with Brazilian reality and the country's elite.

His studies at the École Normale Supérieure gave Georges Dumas the opportunity to build an academic network upon which he could draw in his exchanges with Latin America. Majority of lecturers and teachers whom he advised to go to Brazil (at least in the field of psychology) were also from the École Normale Supérieure. His academic position also helped, because, in addition to his relevant positions, many students and intellectuals attended his classes at the Sorbonne:

"Celles-ci obtinrent vite un succès qui dépassa largement le cercle des étudiants. Aux séances du dimanche matin, c'était une véritable foule qui se pressait, parmi laquelle des médecins, des avocats, des ecclésiastiques, des écrivains, des journalistes, des gens du monde, des curieux attirés par sa renommée. [...] La vaste audience de son enseignement, qui ne s'est pas démentie au cours des temps, répondait bien à l'intérêt que pouvait susciter dans le public, la psychologie, science encore nouvelle. Mais c'est surtout aux dons personnels de Dumas qu'elle est due" (Wallon, 1968, pp. 122-123). ${ }^{3}$

Suppo (1999) adds that for twenty years, Georges Dumas was considered by French diplomatic circles indispensable for the development of French intellectual influence, due to his oratory talent, his

2 A digital version of this newspaper is available at http:// hemerotecadigital.bn.br

3 "They quickly obtained a success that greatly exceeded the circle of students. At the Sunday morning sessions, it was a veritable mass that crowded around, among which there were doctors, lawyers, clerics, writers, journalists, people of the world, and curious people attracted by his renown. [...] The vast audience of his teaching, which did not diminish in the course of time, corresponded well to the interest that the new science of psychology generated. But it is above all to the personal gifts of Dumas that it [the audience] was due." [our translation]. 
ability to forge valuable friendships and the weight of his intellectual authority as a professor at the Sorbonne, and as the author of several published books. Dumas was considered a scientific and political leader and, at the same time, a diplomatic specialist and an ambassador. To refer briefly to his political side, we need to mention his role on the Comité France-Amérique (France-America Committee). ${ }^{4} \mathrm{He}$ was initially a member at the Intellectual and Artistic Section (1924), and then he assumed the vice-presidency of the Brazil Section (in 1930). The next year, he held the position of Président Adjoint (assistant to the President) of the Education Commission, finally becoming president of the France-Brazil Section in 1937.

Beginning in 1926, Georges Dumas participated regularly, as a member of the Executive Board, in the activities of the Alliance Française (French Alliance). Upon returning from each trip, he made a report on the situation of the French language in Brazil. The dissemination of the French language brought by scientific missions was considered as highly desirable by French foreign policies. Georges Dumas was also present at the Service des CEuvres françaises à l'étranger - SOFE (French Works Abroad Service). ${ }^{5}$ He became a kind of deputy director for the SOFE. Some of the most difficult missions were given to him, and he was consulted before any decision (Suppo, 1999). Apart from his personal qualities, Georges Dumas was active in the main institutions created to improve relationships concerning France and Latin America. He had a good French diplomatic network and an important position in the intellectual and academic circuit. This network also enabled him to initiate and to coordinate an important book in the field of psychology.

4 According to Martinière (1982), the France-America Committee was founded at the end of 1909. Its actions complemented and supported the Groupement. Both institutions formed the base of the academic cooperation between France and Brazil. The idea was to unite the two countries and to expand knowledge of Latin America in France and of France in Latin America.

5 The SOFE was created in 1919 by the General Secretary of the Ministry of Foreign Affairs (MAE), and it promoted French scientific exchanges by providing significant funding. The sources in the MAE were an important part of our research.
Documents found about Georges Dumas are mainly those conserved by the French Ministry of Foreign Affairs. Partly because of the available sources, more diplomatic information about the role of Georges Dumas in Brazil was found. In order to evaluate scientific exchanges between France and Brazil, promoted by Georges Dumas, his Traité de Psychologie and the Nouveau Traité de Psychologie were examined, aiming at analyzing possible Brazilian contributions and looking for real exchanges from both sides (French and Brazilian). Even knowing that contributions from each scientific community might have been unequal, we tried to check a possible Brazilian cooperation to the book.

The Traité de Psychologie and the Nouveau Traité de Psychologie.

In the Traite de Psychologie, organized by $\mathrm{Du}$ mas, there were no Brazilian collaborators among the authors of the book. The Traite was divided in two volumes that appeared in 1923 and 1924, respectively. Both volumes are subdivided in books, which in turn are subdivided into chapters. Different authors wrote these chapters. Lourenço Filho (1955) argues that in the first version of the Traité de Psychologie, Dumas and his collaborators cited few Brazilian authors, whereas about a dozen Brazilian authors were quoted ten years later in the next edition of the Nouveau Traité de Psychologie. The second version of the book was revised and expanded from 1930 until 1949. However, it remained unfinished.

The first version of the Traite de Psychologie has 25 authors, mostly French. Among the researchers who have contributed to the book we found no Brazilians or Latin Americans. All authors were Europeans. Théodule Ribot, whom Georges Dumas considered as his master, presented the first volume with a preface. According to Wallon (1968), Georges Dumas dedicated the book to Ribot, who had both encouraged and directed the project. The first Brazilian work mentioned in the first version of the book is an article written by Medeiros e Albuquerque, a journalist and writer, member of the Brazilian Academy of Letters. The article had been published in France, in 1911, in the Journal de Psychologie Normale et Pathologique, a periodical 
founded by Georges Dumas and Pierre Janet in 1903 (Medeiros e Albuquerque, 1911).

Quote at volume I, fourth book Les formes générales d'organisation (The general forms of organization), Chapter II L'association des idées (The association of ideas), the chapter was written by J. Dagnan and revised by Henri Delacroix and Georges Dumas (Dagnan, 1923). In the second version of Dumas's book (Dumas, 1934), the chapter on the association of ideas becomes Chapter III, it is written by Henri Delacroix, and the reference to Medeiros e Albuquerque is no longer there. However, this is the only reference in the first version of the book that is also found in the new version, but in a different chapter.

The second and the third works cited in the Traité were also written by Medeiros e Albuquerque. Both quotations were found in Volume II, Book III Sciences Annexes (Annex sciences), Chapter VI Psychologie Pathologique (Pathological Psychology) (Dumas, 1924). Georges Dumas wrote the chapter, and it disappears in the Nouveau Traite de Psychologie, along with the citations. Both texts were published in the early 1920s in Portuguese, in Brazil, and refer to the theory of human sexuality and hypnotism of Freud (Medeiros e Albuquerque, 1922, 1923). One more Brazilian text is cited in the Traité de Psychologie, written by Mauricio de Medeiros, Medeiros e Albuquerque's brother. The work is also mentioned by Georges Dumas in Chapter VII of Book III, Volume II, (Medeiros, 1922).

Georges Dumas made all references. The Brazilian brothers are the sons of José Joaquim da Costa Campos de Medeiros e Albuquerque. Medeiros e Albuquerque (1867-1934) is currently best known for his literary role. Writer and journalist, he was one of the founders of the Brazilian Academy of Letters where he occupied the chair number 22 since 1899 . However, mainly during the 1920 s, he dedicated some publications to psychology, as we can see from the texts mentioned in the Traite de Psychologie. As director of Public Instruction in Rio de Janeiro, he promoted the transformation of Pedagogium, previously a pedagogical museum, in a higher learning institution in the field of education and established there the first Laboratory of
Experimental Psychology in Brazil. Medeiros e Albuquerque is considered one of the first authors to disseminate in Brazil the theory of emotions from William James (Campos, 2001). As we can see from the text mentioned in Dumas Traité de Psychologie, he was probably one of the first scholars to circulate Sigmund Freud's psychoanalysis in Brazil, as well.

Medeiros e Albuquerque also published in 1924 a book about intelligence tests (Medeiros e Albuquerque, 1924). The book reached several editions. It presents an extensive, annotated bibliography of books and articles about intelligence and educational tests. Majority of references were written in English, and, in this regard, Medeiros e Albuquerque (1924) explained that those who wanted to study tests in Brazil were faced with the lack of sources in Portuguese, as majority of references came from France ${ }^{6}$. Although it was Alfred Binet who introduced the use of tests in psychology, his initiative did not continue in his own country. Medeiros e Albuquerque (1924) cited the journal Année Psychologique, with some publications by Henri Piéron and his wife, and explained that the majority of publications on the subject were written in English, because the United States had taken the leadership of the testing movement.

According to Gomes (2004), if, on one hand, experimentation had gained to psychology the status of science. Tests, on the other hand, gave it a practical extension in many areas. Laboratories legitimized psychology as an independent field of knowledge. Analogously, tests provided psychology with an application in education, in professional guidance and in industrial companies, allowing an extension of the field of psychology. In this area, however, France was no longer a reference, even if many attempts were made to adapt Binet-Simon's tests to Brazilian reality. Some of these adaptations were performed by Isaías Alves in Bahia (Antunes, 2005), Ernani Lopes in São Paulo, Ulysses Pernambucano in Recife, Manoel Bomfim in Rio de Janeiro (Lourenço Filho, 1929) and Helena Antipoff in Minas Gerais (Bandeira de Melo \& Campos, 2013).

6 Like in Argentina (Taiana, 2006). 
Medeiros e Albuquerque lived for a few years in Europe, especially in Paris. Henri Allorge (1911) presents Medeiros e Albuquerque as the founder of the Courrier du Brésil, which is considered a useful newspaper for the Brazilian colony in France. During his stay in Paris, Medeiros e Albuquerque gave lectures about Brazilian literature (Journal de débats politiques et littéraires, 1912, June 6). During the First World War, he supported Brazil's entry into the war on the side of the Allies. He made a major campaign in the newspaper A Noite not only for the participation of Brazil in the war but also for the breaking of Brazilian diplomatic relations with Germany. In February 1915, Medeiros e Albuquerque gave a lecture entitled Brazil and the European war, where he spoke in favor of the Allies and against Brazilian relations with Germany (A Noite, 1915, February 11). He put forward the argument that France, England and Belgium have always helped Brazil, while Germany never did it. He maintained that Brazilian moral and intellectual cultures were mainly due to France. According to him, even intellectuals of other nationalities were known in Brazil through French literature. He claimed that everything arrived in Brazil from France or by France. Antonio Candido (interviewed by Pontes, 2001, p. 6) confirms: "Muitos dos livros em português a que tínhamos acesso eram traduções das coleções francesas." 7

Georges Dumas also cited Mauricio de Medeiros in his Traité de Psychologie. Mauricio de Medeiros was Medeiros e Albuquerque's brother. Despite the medical text cited by Dumas, the medical thesis of Mauricio de Medeiros was presented in 1907 as Os Métodos da psicologia (The Methods of Psycho$\log y)$. Mauricio de Medeiros attended Georges Dumas's lectures, and together they developed an original dynamograph ${ }^{8}$ (Lourenço Filho, 1955). After Medeiros went to Paris, he established a Laboratory of Experimental Psychology in Rio de Janeiro, probably the second psychology laboratory in the country. According to Olinto (2004), some

7 "Many of the books in Portuguese that we had access to were translations from French collections" [our translation].

8 A dynamograph serves to measure the muscular power. of the instruments ordered for this laboratory came from Europe.

Mauricio Medeiros was the secretary of the Pro Allies League during the First World War. Like his brother, he supported the participation of Brazil in the conflict to help the allies. He went to Europe, where he participated in the closing session of the Latin America week in Bordeaux (Medeiros, 1955). Martinière (1982) mentions three Latin America weeks in France that took place in Lyon, Paris and Bordeaux in 1916, 1917 and 1918, respectively.

Compangon (2009) explains that Brazil and other Latin America countries had declared their neutrality ${ }^{9}$ in the conflict for several reasons, such as 1) the Monroe Doctrine; ${ }^{10}$ 2) the economic dependence of Latin America on foreign countries; 3) the preservation of the integrity of the country built by a large number of European immigrants. This last reason applies especially to Brazil, which had a community of Germanic origin with about 400.000 members, mostly located in the South and in the Southeast (São Paulo, Santa Catarina and Rio Grande do Sul) and deemed badly integrated.

When, in 1917, Brazil entered the war on the side of the Allies, Medeiros e Albuquerque, who was openly in favor of Brazil's direct participation in the conflict, sent a telegram to the Académie Française (French Academy) to express his satisfaction, adding that the nations were fighting for the great cause of civilization and that the French Academy ${ }^{11}$ had always been a model for the Brazilian Academy (Journal Officiel de la République Française $^{12}$, 1917, November 23, p. 9456).

Connections between war and the scientific circulation concerning Europe and Latin America were direct. Petitjean (1996) explains that, with the

9 The Brazilian neutrality was declared initially by the Decree 11.037 of August 1914 and then completed by a series of other decrees (Compagnon, 2009).

10 The Monroe Doctrine dates from 1823 and established the principle of the non-interference of the American Countries in European affairs in exchange for the non-interference of Europe in America.

11 In the article about Dumas's death, the newspaper A Noite, from May 1946, said that he was the official correspondent in France to the Brazilian Academy.

12 Available at http://gallica.bnf.fr 
approach of the First World War, German, English and French universities tried to attract students and foreign scholars, including Americans, hoping that, when they returned to their country, they would become declared allies. The scientific exchanges aimed at the same time to expand an economic market and to extend diplomatic relations. Medeiros e Albuquerque and his brother Mauricio Medeiros studied in France, and they are both examples of the elite who had a strong connection with the French culture and defended France during the war. Better yet, both conducted major campaigns to ensure the participation of Brazil into the war on the French side.

In the second version of Dumas' book, Nouveau Traité de Psychologie, we found, as indicated by Lourenço Filho (1955), the citation of ten Brazilians works. Georges Dumas still has no Brazilian collaborator among the authors of the book. They continue to be mostly French, with few exceptions, for example, Jean Piaget, Edouard Claparède and Jean Larguiers des Bancels, who were Swiss. Among the ten works cited, Miguel Osório de Almeida wrote eight.

The Brazilian bibliography in the Traité de Psychologie indicates the relevance of scientific traveling to stimulate the circulation of knowledge. In the first version of the book, both Medeiros e Albuquerque and his brother Mauricio de Medeiros were cited, and both had studied in Paris for a while. In the second version of the Traité, Osório de Almeida is cited eight times with six articles (two of them were repeated). Four works were coauthored, by Osório de Almeida and Piéron (1924a, 1924b, 1924c, 1924c). Other two works by Osorio de Almeida $(1926,1939)$ were cited. Miguel Osório de Almeida was very often in France, and he is one of the founders of several Brazilian scientific societies, such as the Brazilian Academy of Sciences (1916), the Brazilian Education Association (1924) and the Brazilian Society for Scientific Progress (1949). His papers were quoted by Georges Dumas at the Volume IV called Les fonctions et les lois générales ${ }^{13}$

13 Functions and general laws.
(Dumas, 1934) and by Henri Piéron in a text about Zoological Psychology at the fascicle 1, Volume VIII (Piéron, 1941). The papers explored the frog nervous system from a psychophysiological point of view. Other works dealt with the reflexes adaptation problem and the role of the skin in the maintenance of mammals' tonicity. His papers are clearly in the field of physiology. To avoid anachronism, it is important to mention that psychology was not an independent science at this time in either France or Brazil. Doctors, physiologists and event engineers performed research in psychology. That is why many of the Brazilian papers may seem distant from psychology.

Other papers quoted in the second Traité were Lourenço Filho's work on the experimental study of habits (Lourenço Filho, 1927) and Medeiros e Albuquerque study on the phenomenon of synopsy (Medeiros e Albuquerque, 1911), already cited in the first treatise. Among Brazilians studies appearing in the second version of the Traité, Lourenço Filho's paper can be considered closest to what we think now of as being the psychology field, but he had just one quotation in the entire book, probably because he was a younger author at the time. In the following years, he developed constant relations with France, having been admitted to the Société Française de Psychologie (Lourenço Filho, 1955) and also a guest at the Jubilee of French scientific psychology. The event was also a tribute to the centenary of Ribot and Lourenço Filho's paper called La pensée de Ribot dans la psychologie sudaméricaine (The thought of Ribot in the South American psychology) was published at the Centenaire de Th. Ribot - Jubilé de la psychologie scientifique française (The centenary of Ribot - Jubilee of French scientific psychology) in 1939 (Lourenço Filho, 1939). Lourenço Filho (1955) defines himself as a disciple of Henri Piéron.

In general, Brazilian studies published in the Traité de Psychologie do not represent a significant number $(12$ citations in total along the two versions of the book). There were several studies cited in English, German, Spanish and Italian, as well. Brazilian psychology was developing, and the connections with the French tradition were a means of assistance for this development. We may 
wonder whether Brazilian authors had no more important contributions to offer to the book, or if they hadn't enough legitimacy to have a more consistent involvement.

\section{Georges Dumas's Travels to Brazil and} the French Conferences in the Country

Georges Dumas's first traveled to Brazil in 1908, upon invitation by Mauricio de Medeiros. Martinière (1982) considered this trip as a turning point in Georges Dumas's career. He arrived in Brazil in a moment when there was euphoria in the country due to Oswaldo Cruz's victory against the yellow fever. As a former student of Institute Pasteur, in Paris, Oswaldo Cruz's actions in the Brazilian health system opened the doors to French scientific production, mainly in the medical field (Martinière, 1982). During his stay, Georges Dumas was surprised by Brazilians' loyalty to the French language, literature, science and culture. Ignorance of French scholars about Latin America, was to him, on the contrary, most shocking (Petitjean, 1996).

The Groupement des Universités et Grandes écoles de France pour les relations avec l'Amérique latine developed many ways to improve scientific and cultural exchanges with Latin America, such as a journa $1^{14}$ published from 1910 until 1932, a committee to welcome foreign students in France and the foundation of the Maison des Nations Américaines (American Nations House) in Paris in 1927 (for more details about the network of exchanges between France and Brazil, see Hamburquer, Dantes, Paty, \& Petitjean, 1996; Martinière, 1982). With money from the Fonds pour l'expansion universitaire et scientifique de la France à l'étranger (France academic and scientific expansion abroad funds), set up in 1912, and the SOFE, the foreign exchanges were ensured. To give an idea of the importance of Georges Dumas's mission, we must say that he went approximately eighteen times to South America.

14 The journal changed its name three times: Bulletin de la Bibliothèque américaine (American Library Bulletin), Bulletin de l'Amérique latine (Latin America Bulletin), Revue de l'Amérique latine (Journal of Latin America) (Suppo, 1999).
According to Martinière (1982), the mentioned journal had a reduced scientific dimension. The concept of "Latinity" 15 was widely defended against the Anglo-Saxon influence and against a domination of the United States on Latin America. The idea was that there should be a union between Latinos, who should defend their culture. A common kinship, the similarity of languages and especially a similar orientation of the general culture were some reasons to legitimize a Latin-American perspective. In this case, France was the best country to show its American cousins the path to a better civilization, informed by modern science (Petitjen, 1996; Romero Sá \& Viana, 2013).

In 1912, Georges Dumas returned to Brazil to give conferences. Upon the inauguration of the Union scolaire Franco-Paulista (UEFP), in São Paulo, his lecture was entitled The Psychology of Pierre Janet and Pathological Psychology. He traveled on an official mission of the Groupement. The President of the UEFP, Rodrigues Bittencourt, opened Georges Dumas's conference by thanking the latter for his effort to establish a deeper relationship between French and Brazilian scientific and academic communities (O Estado de São Paulo ${ }^{16}$, 1912, October 1).

Rodrigues Bittencourt believed that a true exchange was established between the two countries. Among scholars circulating in both directions, Georges Dumas was the only representative of the field of psychology. The description of Georges Dumas's lecture in a newspaper article (O Estado de São Paulo, 1912, October 1) shows that, before

15 Martinière (1982) explains that the term "Latin", used to describe the former Spanish and Portuguese America, was due to Napoleon III during a mission in Mexico. In order to replace other names like Spanish-America, New Spain or New Granada aiming at legitimizing his intervention in that country. Despite the failure of this French mission, the term became popular in America. By adopting this name, American elites, who had rejected the political domination of Spain and Portugal, proclaimed their originality against their old colonialists and the expansion of U.S. imperialism Chonchol, Martinière, \& Blanca (1985). We recommend two books as good examples of this kind of speech: Prado (2005), as a Brazilian point of view, and Gaillard (1918), as a French point of view.

16 Article called Professor G. Dumas from the newspaper O Estado de São Paulo published at São Paulo, page 2, with a digital version available at http://acervo.estadao.com.br 
speaking about Pierre Janet's psychology (the theme of the conference), he summarized a brief history of psychology in France. He mentioned, for example, Descartes, Egger and Gall as pioneers in the field. He cited Victor Henry, Henri Piéron, Broca and Carpenter as representatives of psychophysiology and Théodule Ribot for pathological psychology. Janet was chosen for the conference because he had systematized the work of Ribot. The conferences were also mentioned by the newspapers O Pais and A Manha ${ }^{17}$.

George Dumas returned to Brazil from July 1917 to March 1918, when he was sent by the French government to recruit Brazilian doctors to help in the War (Martinière, 1982). Moreover, he was assigned other missions during the War, as a member of the 3rd Army and as an inspector of mental health hospitals. The newspaper A Noite (November 18, 1917) reports that Georges Dumas was received in Juiz de Fora (Minas Gerais) by the Allied League from Minas Gerais. The mission in Brazil was successful, since Brazil made a donation for the construction of a hospital in France and sent some doctors to help in the War. The Brazilian participation on the Allied side was described by Compagnon (2009) as: a naval mission on the African coast, an air mission with thirteen officers at the Royal Air Force and a medical mission in Paris.

During the 1920s, the largest part of French conferences in Brazil took place at the Institut franco-brésilien de haute culture. In theory, all these institutes were run in the same way: one to three French academics should give classes during two or three months in Latin America and vice versa. The funding was divided equally between the two countries. Each time, two committees were planned, one in France and one in the country concerned. The Latin American Committee chose scientific disciplines and provided some names.

French participation in the celebrations of the Brazilian independence centenary with an exhibition at Rio de Janeiro in 1922 is a good example of

17 Brazilian newspapers with a digital version available at http:// hemerotecadigital.bn.br the major conferences of this period. ${ }^{18}$ In the organization of this event, we can observe some important elements in the exchanges between France and Brazil, such as the competition between European nations, economic interests and the role of science in changing the image of Brazil in Europe. On the one hand, France described Brazil as a potential place to invest based on the promises of its future growth; on the other hand, Brazil wanted to show advances since its independence from Portugal, in the nineteenth century, and needed help to move forward.

In 1930, fifteen French teachers traveled to Latin America (Petitjean, 1989). Between 1922 and 1939, forty-one French professors went to Rio de Janeiro (Petitjean, 1996). In the field of psychology there were conferences organized by Georges Dumas, Henri Piéron, Pierre Janet and Henri Wallon. Souces found in their archives at Bibliothèque Piéron (Henri Piéron Library at Paris University René Descartes), at the Collège de France (College of France) and the Archives Nationales (French $\mathrm{Na}$ tional Archives) respectively show that Henri Piéron visited Brazil in 1923, 1926 and 1947 (Piéron, 1992) and lectured about Experimental Psychology; Pierre Janet went to Brazil in 1922 and 1933 for conferences about pathological psychology; Henri Wallon visited São Paulo, Rio de Janeiro and Salvador, speaking about several subjects such as the psychology of childhood, puberty and determinism in psychology. Wallon (1968) traveled to Rio de Janeiro in 1935, together with Georges Dumas, and observed how much Dumas was loved there. The latter was named an honorary citizen of Rio de Janeiro, and, according to Wallon, he was happy and proud of it.

Despite the good relations between France and Brazil, some criticisms of the French conferences were made. Some of them were directed to the French university system - considered fragmented with respect to teaching and researching. The priority of the French university system seemed to be

18 The documents concerning the French participation in the Brazilian centenary were all found at the French Ministry of Foreign Affairs. 
teaching. Research was made in other institutions such as the Natural History Museum, Pasteur Institute and the École Normale Supérieure. Fernando Azevedo believed that the conferences given in Rio de Janeiro and São Paulo were good, but luxurious (Petitjean, 1996). He defended the need for higher education without career goals, which meant training researchers to build pure science. He also defended a reform of secondary education.

For Miguel Osório de Almeida, French conferences in Brazil should be less "cultural" and more scientific (Suppo, 1999). For him, it was not enough to have prestigious French professors giving lectures; he wanted specialized scientists focused on the latest scientific advances, promoting the education of Brazilian students and scientists. Osório de Almeida aspired the continuity of scientific cooperation, and though that conferences should be held by longer periods of visiting at research laboratories, in both directions. He asked for a longer duration for the visits of French professors, as well as a system of scholarships for students from both countries, besides the creation of a research institute in common with France and Brazil. Petitjean (2001) explains that Brazilian scientists realized the limits of the Groupement, especially because of its subordination to French diplomacy.

Those criticisms and demands converge on the French mission within Brazilian universities, beginning in São Paulo. The 1934 French academic mission was no longer a series of cultural conferences, but included a group of professors responsible for teaching and research activities at the newly created University of São Paulo, more specifically at the Faculty of Philosophy, Sciences and Letters. Due to the success of this mission, something similar was proposed to the University of Brazil, in Rio de Janeiro, the capital of the republic.

\section{Georges Dumas and the French missions at Brazilian universities}

In contrast to the three-month contract of Groupement, French professors hired by Brazilian Universities had in general a three-years contract. They were no longer expected to represent French culture, but to help Brazilian students to learn about their own country, reducing Brazilian dependence on foreign intellectual production. This new moment represented more intellectual autonomy for Brazilian students and also for French tutors, contrary to the guidelines existing within the activities of the Groupement Petitjean (1996B).

Brazilian elites wanted to assign to France the chairs covering disciplines that taught how to think. They did not want to trust such a mission to representatives of totalitarian countries. According to Julio de Mesquita Filho ${ }^{19}$ (cited by Patrick Petitjean, 1996B), São Paulo's elite was essentially liberal in a time when liberalism had disappeared in Europe, and the selection of professors was made in order to promote liberalism. In the beginning of the twentieth century, Italian and German immigration was sturdy in Brazil, and families of already established immigrants pressured authorities to reserve a large part of university chairs for Italians and Germans. To answer these pressures, USP creators decided to assign them some chairs in the hard sciences, while the chairs that were considered to influence directly the mentality of future students were reserved to French scholars, considered the leaders of liberal democracy (Ferreira, 1999). The resolution of this conflict made Brazilian social sciences (as we call them today) highly based on French ideals.

Arantes (1994) considers the University of Sao Paulo Faculty of Philosophy, Sciences and Letters a Departamento Francês Ultramar (French Overseas Department - our translation). The French government paid part of the salaries, as we can see in documents made by Arbousse-Bastide (1936) ${ }^{20}$ about the French mission. Ferreira (1999) studied the same letters and shows how politicians considered this scientific mission as an occasion to improve French political and cultural influence in Brazil. They also wanted to ensure political allies, in case of a possible war, in any case in the future.

19 Julio de Mesquita Filho is considered responsible for the creation of the USP.

20 Letters to Jean Marx (Minister of Foreign Affaires) found at the French Ministry of Foreign Affairs Archives. 
Once psychology at this period was not yet considered as an independent science, its teaching was assigned to French philosophers. Etienne Borne was the first to assume psychology classes, and, later, Jean Maugüé was invited to replace him. Maugué stayed in São Paulo from 1935 until 1944. Only André Ombredane stayed as a psychology teacher at the University of Brazil, in Rio de Janeiro, from 1939 to 1945. Also in Rio, Etienne Souriau and Émile Brehier each served as chair of philosophy at the Universidade do Distrito Federal, which in 1937 was incorporated by Universidade do Brasil (later on named Universidade Federal do Rio de Janeiro) (Fávero, s/d; FGV/CEPDOC, 2014; Lefebvre, 1990; Lourenço Filho, 1955; Penna, 1992).

To give some concrete examples, according to Costa Neto (2007) Jean Maugüé taught at USP: perception (starting with the history of philosophy, passing by experimental psychology and Gestalt psychology; memory and personality (including the pathological psychology of Pierre Janet, and psychoanalysis). According to Penna (1992) Ombredane taught in Rio a first year with an introduction to philosophical and scientific psychology (including Greek thinkers, behaviorists, reflexology, Gestalt psychology and psychoanalysis), in the second year he presented the evolution of psychological thought from the late nineteenth to the early twentieth century, and finally, in third year, he focused the origin and development of contemporary psychological systems with a study of different psychological processes (perception, memory, feelings and emotions, motivations and attitudes, thought and expression, and intelligence).

Lévi-Strauss participated in the 1934 French mission at USP, and claimed that the foundation of the University of São Paulo was Georges Dumas's greatest work (Lévi-Strauss, 1955). The reasons for the success of the French mission in Brazil and the good reception of Georges Dumas in the country are the result of a complex situation. As explained earlier, Brazilian urban elites considered French cultural influence as a strategy that could contribute to the solution of some problems faced at the time in their efforts to modernize the country. Changing the reputation of Brazil in Europe was needed. The country was considered unhealthy, with a high risk of contamination of diseases for its visitors. Georges Dumas and Germain Martin (1926) revealed that, for them, for the cultural and scientific French transplant to be valid and to have a chance of success, it should contribute both to the solution of some Brazilian problems and to transform Brazilian image in Europe. Georges Dumas's actions would ultimately lead to a change in the Brazilian image both inside the country and abroad.

Dumas's connections with positivism could be another branch for our analyses. In his Latin thesis $^{21}$, Georges Dumas wrote about Auguste Comte and his critiques of the psychology of his time. $\mathrm{He}$ also published a book about Saint-Simon and Auguste Comte (Dumas, 1905). In Brazil, positivism has been an important success, greatly influencing the first generation of republicans after the proclamation of the republic, in 1889. An article found at French Ministry of Foreign Affairs Archives ${ }^{22}$ discusses Auguste Comte and Saint-Simon's influence in the "New World." The text mentions several relevant factors. The first is the French influence on Brazilian academic culture, which could be observed from north to south. Then some examples are given concerning the introduction of science in society with the multiplication of institutions of public education, higher learning centers, companies and societies devoted to the cult of science, literature and the arts, academies, colleges, libraries, schools, etc.

Brazil underwent an important development in many ways during this period. Educational institutions were highly valued, and science began to occupy a privileged place in society. At this time, psychology served as a tool for professionalization in various urban sectors in Brazil, and psychological instruments were used to expand knowledge on psychosocial characteristics of urban population (Campos, 2006). The process of development is illustrated by the creation of research and higher

21 In France at this time students had to defend a thesis in French and another one in Latin.

22 Newspaper published in Rio de Janeiro probably from September 1922. Article call Idées franco-brésiliennes and found at the Ministry of Foreign Affairs Archives. 
learning institutions, as well as the participation of Europe, especially France, in this evolution.

That is exactly where we see the role of Georges Dumas in the development of psychology. Georges Dumas was ready to offer what the country aspired. He brought to Brazil the sciences that were considered important to improve and modernize the country. All of these ideas were consistently harmonious with positivism. Also, we remember that the Brazilian flag bears the words "Order and Progress." However, Suppo (1999) said that Brazilian positivists sidelined Georges Dumas, but because of his political considerations he could maintain good relations with positivists there.

\section{Discussion}

Based on our knowledge of Georges Dumas's role in Brazil, we can realize the nature of French participation in the development of Brazilian Psychology. We have identified two distinguished periods: a moment where French academics went to Brazil to give lectures and, after that, an even more important presence of French professors teaching at the newly established Brazilian universities. In psychology, in the first period, Georges Dumas, Henri Piéron, Pierre Janet and Henri Wallon were in Brazil. As professors in Rio de Janeiro and São Paulo, André Ombredane was a psychology teacher, and Etienne Borne, Jean Maugüé, Etienne Souriau and Émile Brehier were philosophers teaching psychology.

The exchange between France and Brazil was a consequence of the desires of both countries. To better understand this context, we need to step out the scientific world to look at political and social issues. On the one hand, France wanted to increase its cultural influence in Latin America in order to preserve its intellectual and political leadership in Europe and the world. On the other hand, Brazilian elites needed to modernize the country and to show its development to the world. The competition between certain countries in Europe favored the French presence. With the First World War this rivalry grew even bigger. Scientific exchanges were beyond the academic sphere. Medeiros e Albuquerque and his brother Mauricio de Medeiros were good examples of that, as they supported France in diplomatic issues.
Scientific exchanges were beneficial from the standpoint of the political context. Brazil welcomed French scholars to conferences in order to improve its higher education system. At the same time, France wanted to spread the influence of its language, science and culture. Canêdo and Garcia (2004-2005) explain that the intensity of the flow of students and researchers to Europe is one of the best indicators of scientific and cultural supremacy of a country. In addition, the wealth and the power of a country can be seen from its education and scientific research support system.

In order to better understand the evolution of psychological studies in Brazil from the standpoint of Brazilian-French connections, many issues deserve to be further explored. First of all, the analysis of the contents of the topics covered in French conferences and classes in Brazil can illuminate the characteristics taken by the field of psychology in the first decades of the twentieth century. Then, a second step could be taken, looking at these relationships in another sense, from the perspective of scientific circulation. It means that movements in both directions should be observed: from France to Brazil and from Brazil to France. We tried to approach Brazilian participation in French psychology by studying the Traité de Psychologie. Other paths could open new ways to explore mutual influences in the field, and this panorama can be considered a beginning, without which bigger advances would not be possible. French missions reached other regions and universities in Brazil, such as Porto Alegre University, in Rio Grande do Sul. Also some psychological laboratories established in other regions received the help of foreign professionals, and their influence on the subsequent development of Brazilian psychology should be studied.

\section{References}

Allorge, H. (1911, January). Notes de littérature brésilienne. Le penseur, pp. 16-21.

Antunes, M. A. M. (2005). A psicologia no Brasil: leitura histórica sobre sua constituição. (4th. ed.). São Paulo: Unimarco Editora/Educ.

Arantes, P. E. (1994). Um departamento francês de ultramar. Rio de Janeiro: Paz e Terra. 
Arbousse-Bastide, P. (1936). Letters to Jean Marx (Oeuvres-Brésil, Carton n 443). Nantes, Fr: Archives Diplomatiques.

Bandeira de Melo, C. S., \& Campos, R. H. F. (2013). L'expérience d'Helena Antipoff dans le laboratoire de psychologie de Binet-Simon à Paris : apprendre en faisant. In M. Sorokina, (Org), The global educational space and academic migrants: The legacy of the Russian psychologist Helena Antipoff (1892-1974) in Education and Human Rights in Latin America, Europe and Russia. Moscow: Solzenitcyn Russia Abroad House.

Cabral, A. C. M. (2004). A Psicologia no Brasil (1950). In M. A. M. Antunes (Org.), História da Psicologia no Brasil: primeiros ensaios (pp. 33-70). Rio de Janeiro: EdUERJ/Conselho Federal de Psicologia.

Campos, R. H. de F. (Org.). (2001). Dicionário biográfico da psicologia no Brasil: pioneiros. Rio de Janeiro: Imago.

Campos, R. H. F. (2006). Scientific psychology in Brazil in the $20^{\text {th }}$ century: The dialogue with European researchers, a look at Brazilian culture and a successful process of professionalization. Physis, Rivista Internazionale di Storia de la Scienza, 43(1-2), 301-318.

Canêdo, L., \& Garcia, A. (2004-2005). Les boursiers brésiliens et l'accès aux formations d'excellence internationales. Cahiers du Brésil Contemporain, 57/58-59/60, 21-48.

Carroy, J., Ohayon, A., \& Plas, R. (2006). Histoire de la psychologie en France: XIXe-XXe siècles. Paris: La Découverte.

Compagnon, O. (2009). Entrer en guerre? Neutralité et engagement de l'Amérique latine entre 1914 et 1918. Relations Internationales, 137, 31-43. Retrieved from http://halshs.archives_ouvertes.fr/ view_by_stamp.php?\&halsid=9trtc $26 \mathrm{crtd} 1 \mathrm{~m} 4 \mathrm{ji}$ 46ama2f8f2\&label $=$ SHS\&langue $=$ fr\&action todo $=$ view\&id $=$ halshs -00371287 \&version $=1$

Costa Neto, P. L. (2007). A missão francesa e o ensino na Faculdade de Filosofia Ciências e Letras da Universidade de São Paulo (FFCL - USP). Retrieved from http://www.portalanpedsul.com.br/admin/uploads/2004/ Painel/Painel/04_48_35_A_MISSAO_FRANCESA_E_O_ENSINO_NA_FACULDADE_DE_FILOSOFIA_CIENC.pdf
Chonchol, J. \& Martinière, G. (1985). L'Amérique latine et le latino-américanisme en France. Paris : L'Harmattan.

Dagnan, J. (1923). Lassociation des idées [The association of ideas]. (H. Delacroix \& G. Dumas, Rev.). In G. Dumas (Ed.), Traité de psychologie (Vol. 1, Book 4, Chapter 2, pp. 820-845). Paris: Félix Alcan.

Dumas, G. (1905). Psychologie de deux messies positivistes: Saint-Simon et Auguste Comte. Paris: Félix Alcan.

Dumas, G. (1924). Sciences annexes. [Annex sciences]. In G. Dumas (Ed.), Traité de psychologie (Vol. 2, Book 3, Chapter 6, pp. 1007-1070). Paris: Félix Alcan.

Dumas, G. (1934). Les fonctions et les lois générales [Functions and general laws]. In G. Dumas (Ed.), Nouveau traité de psychologie (Vol. 4e, pp. 386-411). Paris: Félix Alcan.

Dumas, G., \& Martin, G. (1926). Une grande ville de l'Amérique du Sud: Rio de Janeiro, capitale du Brésil. Journal L'Illustration.

Fávero, Maria de Lourdes A. (s/d). A Universidade Federal do Rio de Janeiro: origens e construção (1920 a 1965). Retrieved from http://www.sibi.ufrj.br/ Projeto/artigo_mariadelourdes.pdf

Ferreira, M. M. (1999). Os professores franceses e o ensino da história no Rio de Janeiro nos anos 30. In M. C. Maio \& G. Villas Bôas (Org.), Ideais de modernidade e sociologia no Brasil: ensaios sobre Luiz de Aguiar Costa Pinto (pp. 277-299). Porto Alegre: Ed. Universidade/UFRGS.

Fundação Getulio Vargas/Centro de Perquisa e Documentação de História Contmporânea do Brasil. (2014). Anos de Incerteza (1930-1937). Rio de Janeiro: Universidade do Distrito Federal. Retrieved from http://cpdoc.fgv.br/producao/dossies/AEraVargas1/anos30-37/RadicalizacaoPolitica/UniversidadeDistritoFederal

Gaillard, G. (1918). Amérique latine et Europe occidentale: L’Amérique latine et la guerre (Vol. 1). Paris: Berger-Levrault.

Gomes, W. B. (2004). Avaliação psicológica no Brasil: Tests de Medeiros e Albuquerque. Avaliação Psicológica, 3 (1), 59-68.

Hamburguer, A. I., Dantes, M. A. M., Paty, M., \& Petitjean, P. (Orgs.). (1996). A ciência nas relaçöes BrasilFrança (1850-1950). São Paulo: FAPESP. 
Lefebvre, J. -P. (1990). Les professeurs français des missions universitaires au Brésil (1934-1944). Cahiers du Brésil Contemporaine, 12, 1-10.

Levi-Strauss, C. (1955). Tristes tropiques. Paris: Plon.

Lourenço Filho, M. B. (1927). Contribuição ao estudo experimental do hábito [Contribution to the experimental study of habit]. Revista de Biologia e Hygiene, 1, 23-37.

Lourenço Filho, M. B. (1929). [Prefácio do tradutor]. In A. Binet \& Th. Simon, Testes - para a medida do desenvolvimento da inteligência, nas crianças. São Paulo: Melhoramentos.

Lourenço Filho, M. B. (1939). La pensée de Ribot dans la psychologie sud-américaine [The thought of Ribot in the South American psychology]. In T. Ribot, Centenaire de Th. Ribot: Jubilé de la psychologie scientifique française, 1839-1889-1939. Agen: Imprimerie Moderne.

Lourenço Filho, M. B. (1955). A psicologia no Brasil. In F. Azevedo (Org.), As ciências no Brasil [Sciences in Brazil]. São Paulo: Melhoramentos.

Martinière, G. (1982). Aspects de la coopération franco-brésilienne: transplantation culturelle et stratégie de la modernité. Grenoble, France: Presses Universitaires de Grenoble.

Medeiros, M. (1907). Os Métodos da psicologia [The Methods of Psychology]. (Non published $\mathrm{PhD}$ thesis). Faculdade de Medicina do Rio de Janeiro, RJ, Brazil.

Medeiros, M. (1922). Colloïdoclasia: Synthesis actual da questão [Colloïdoclasia: Current Synthesis of the Issue]. Rio de Janeiro.

Medeiros, M. (1955). Discurso de Posse [Inaugural speech at the Brazilian Academy of Letters]. Rio de Janeiro: Academia Brasileira de Letras. Retrieved from http://www.academia.org.br/abl/cgi/cgilua.exe/sys/ start.htm?infoid $=553 \&$ sid $=343$

Medeiros e Albuquerque, J. J. (1911). Sur un phénomène de synopsie présenté par des millions de sujets [About a synopsis phenomenon presented by millions of subjects]. Journal de Psychologie Normale et Pathologique, 8, 147-151.

Medeiros e Albuquerque, J. J. (1912, June, 12). Journal de débats politiques et littéraires. Echos, p. 2. Available at http://gallica.bnf.fr

Medeiros e Albuquerque, J. J. (1922). A Psicologia de um neurologista. Freud e as suas teorias sexuais [The psychology of a neurologist. Freud and his sexual theories]. In Graves e Fúteis. Rio de Janeiro: Leite Ribeiro.

Medeiros e Albuquerque, J. J. (1923) Ohypnotismo [Hypnotism], (2nd. ed.). Rio de Janeiro: Leite Ribeiro.

Medeiros e Albuquerque, J. J. (1924). Tests: introducção ao estudo dos meios scientificos de julgar a intelligencia e a applicação dos alumnos [Tests: Introduction to the scientific means to evaluate students's intelligence and application]. Rio de Janeiro: Liv. Alves.

Olinto, P. (2004). A Psicologia Experimental no Brasil (1944). In Antunes, M. A. M. (Org.), História da Psicologia no Brasil: primeiros ensaios (pp. 25-31). Rio de Janeiro: Ed UERJ/Conselho Federal de Psicologia.

Osório de Almeida, M. (1926). Sur le rôle des excitations d'origine cutanée dans le maintien de l'activité du système nerveux. Journal de Psychologie, 28, 759-771.

Osório de Almeida, M. (1939). Quelques aspects du problème de l'adaptation des réflexes. In T. Ribot (Ed.), Centenaire de Th. Ribot: Jubilé de la psychologie scientifique française, 1839-1889-1939 (pp. 483-496). Agen: Imprimerie Moderne.

Osório de Almeida, M., \& Piéron, H. (1924a). Sur les effets de l'extirpation de la peau chez la grenouille: action de la peau sur l'état général du système nerveux chez la grenouille. Compte Rendu de la Société de Biologie, 90, 420-425.

Osório de Almeida, M., \& Piéron, H. (1924b). Action de la peau sur l'état général du système nerveux chez la grenouille. Compte Rendu de la Société de Biologie (90) 478-481.

Osório de Almeida, M. \& Piéron, H. (1924c). Sur le rôle de la peau dans le maintien du tonus musculaire chez la grenouille. Compte Rendu de la Société de Biologie (90) 1402-1404.

Osório de Almeida, M. \& Piéron, H. (1924d). Sur le rôle de la peau dans le maintien du tonus chez les mammifères. Compte Rendu de la Société de Biologie, 90.

Penna, A. G. (1992). História da Psicologia no Rio de Janeiro. Rio de Janeiro: Imago Editora.

Petitjean, P. (1989, June). Le groupement des Universités et Grandes Ecoles de France pour les relations avec l'Amérique latine et la création d'instituts à Rio de Janeiro, São Paulo et Buenos Aires (1907/1940). In 
Anais do Segundo Congresso Latino-Americano de História da Ciência e da Tecnologia, São Paulo.

Petitjean, P. (1996). Entre ciência e diplomacia: a organizaçäo da influência científica francesa na América Latina, 1900-1940. In A. I. Hamburger, M. Dantes, M. Paty \& P. Petitjean (Orgs.), A ciência nas relaçöes Brasil-França (1850-1950) (pp. 89-120). São Paulo: FAPESP.

Petitjean, P. (2001). Miguel, Paul, Henri et les autres. Les réseaux scientifiques franco-brésiliens dans les années 1930. In Videira, A. A. P. \& Salinas, S. R.A. (orgs). A Cultura da Fisica: Contribuçoes em homenagem a Amelia Imperio Hamburger (pp. 59-94). Editora Livraria da Fisica

Piéron, H. (1941). Psychologie zoologique [Zoological Psychology]. In Dumas, G. (Ed.), Nouveau traité de psychologie (Vol. 8). Paris: Félix Alcan.

Piéron, H. (1992). Autobiographie d'Henri Piéron. In Parot F. \& Richelle M. Psychologie de langue française - autobiographies (pp. 5-30). Paris: Ed. Puf.

Pontes, H. (2001) PONTES, Heloisa. Entrevista com Antonio Candido. REVISTA BRASILEIRA DE CIÊNCIAS SOCIAIS. RBCS Vol. 16 nº. 47 outu- bro/2001. Disponivel em http:/www.scielo.br/pdf/ rbcsoc/v16n47/7717.pdf Acesso em 13 nov 2013.

Prado, E. (2005). A ilusão Americana [1893]. São Paulo: Editora Alfa-Omega.

Rocha, N. M. D. (2004). A Faculdade de Medicina da Bahia e a Preocupação com Questões de Ordem Psicológica durante o Oitocentos. In: Massimi. \& Guedes, M. C. (Orgs) História da Psicologia no Brasil: novos estudos (pp 89 - 107). São Paulo: EDUC e Cortez.

Romero Sá, M., \& Viana, L. M. (2013). La science médicale entre la France et le Brésil : stratégies d'échange scientifique dans l'entre-deux-guerres. Cahiers des Amériques latines, 2010/3(65), 123-143.

Suppo, H. R. (1999). La politique culturelle française au Brésil entre les années 1920-1950. Thèse doctorale, Paris 3, France.

Taiana, C. (2006). Transatlantic Migration of the Disciplines of the Mindo - Examination of the Reception of Wundt's ans Freud's Theories in Argentina. In Brock, A. C. Internationalizing the History of Psychology (pp.34 - 55). New York : NYU Press. 
